\title{
Analisis Kemampuan Pemecahan Masalah Siswa Berdasarkan Rubrik yang Dikembangkan Docktor pada Materi Suhu dan Kalor
}

\author{
Aulia Siska Yuliana ${ }^{1}$, Parno $^{1}$, Ahmad Taufiq ${ }^{1}$ \\ ${ }^{1}$ Pendidikan Fisika-Universitas Negeri Malang
}

\begin{tabular}{l} 
INFO ARTIKEL \\
\hline Riwayat Artikel: \\
Diterima: 06-02-2019 \\
Disetujui: 23-04-2019 \\
\hline
\end{tabular}

\section{Kata kunci:}

problem solving skill; heat and temperature; problem solving rubric; kemampuan pemecahan masalah; suhu dan kalor;

rubrik pemecahan masalah

\author{
Alamat Korespondensi: \\ Aulia Siska Yuliana \\ Pendidikan Fisika \\ Universitas Negeri Malang \\ Jalan Semarang 5 Malang \\ E-mail: parno.fmipa@um.ac.id
}

\begin{abstract}
ABSTRAK
Abstract: This study was aimed to know problem solving skill of senior high school students in heat and temperature. The study was used descriptive-quantitative method and the sample of research was twelve grade students. The instruments that already used as a number of question problem solving skill had 0.732 reliability. The result was analyzed by using rubric of problem solving that already developed by Doctor. The result was obtained that problem solving skill was medium category. This category was included useful description and physics approach. On the other hand, mathematical procedure and logical progression were included as low category.

Abstrak: Penelitian ini bertujuan untuk mengetahui sejauh mana tingkat kemampuan pemecahan masalah siswa SMA pada materi suhu dan kalor. Metode yang digunakan dalam penelitian ini dalah deskriptif kuantitatif dan siswa kelas XII sebagai sampel dalam penelitian ini. Instrumen yang digunakan yaitu tes kemampuan pemecahan masalah dengan reliabilitas 0,732. Data hasil tes dianalisis dengan rubrik kemampuan pemecahan masalah yang dikembangkan oleh Docktor. Hasil peneltian menunjukkan bahwa secara keseluruhan kemampuan pemecahan masalah siswa tergolong dalam kriteria sedang. Kemampuan pemecahan masalah pada kategori useful description, physics approach dan specific application of physics dalam kriteria sedang, sedangkan kategori mathematical procedures dan logical progression termasuk dalam kriteria rendah.
\end{abstract}

Materi suhu dan kalor tergolong materi yang sulit bagi siswa. Kesalahan konsep pada materi ini sering terjadi pada siswa (Silung, Kusairi, \& Zulaikah, 2016; Yolanda, Syuhendri, \& Nely Andriani, 2015). Sebagian besar konsep pada materi suhu dan kalor masih sulit dipahami oleh siswa antara lain konsep suhu, konsep kalor, perpindahan kalor, dan titik didih air (Alwan, 2011). Kurangnya pemahaman siswa terhadap konsep akan berdampak pada kesulitan dalam pemecahan masalah (Azizah, Yuliati, \& Latifah, 2015), sedangkan kemampuan pemecahan masalah sangat dibutuhkan dalam penyelesaian permasalahan kehidupan sehari-hari. Kemampuan pemecahan masalah merupakan salah satu kunci untuk menghadapi abad XXI (Reeve, 2016). Selain itu, kemampuan ini dianggap penting untuk mengahadapi tantangan global saat ini dan dunia kerja pada masa depan seperti membuat keputusan dalam bisnis (Karatas \& Baki, 2013). Oleh karena itu, siswa harus disiapkan untuk menjalani kehidupan dan kerja di abad ini yaitu dalam dunia pendidikan (Scott, 2015) khususnya dalam meningkatkan kemampuan pemecahan masalah.

Kemampuan pemecahan masalah yaitu kemahiran dalam menerapkan informasi pada suatu keadaan untuk menentukan segala sesuatu yang harus dilakukan. Kemampuan pemecahan masalah dapat ditingkatkan dengan melatih siswa. Proses penskoran pemecahan masalah menggunakan rubrik yang dikembangkan oleh Docktor. Terdapat 5 kategori dalam penskoran pemecahan masalah antara lain: deskripsi yang berguna/Useful Description (UD), pendekatan fisika/Physics Approach (PA), aplikasi fisika yang spesifik/Specific Application of Physics (SAP), prosedur matematika/Mathematical Procedures (MP), dan perkembangan logika/Logical Progression (LP) (Docktor \& Heller, 2009). Namun, permasalahan dalam kehidupan sehari-hari tidak sepenuhnya dapat dikatakan sebagai masalah.

Masalah adalah sesuatu yang memiliki keadaan awal, tujuan yang pasti dan operator yang telah diketahui seperti memecahkan persamaan atau operasi penjumlahan angka (Dunbar, 1998). Berdasarkan pengertian masalah tersebut, maka soalsoal dalam fisika juga termasuk masalah. Namun dalam pembelajaran fisika tidak semua soal adalah suatu masalah. Masalah biasanya terdiri dari situasi yang mendorong siswa untuk menyelesaikannya, tetapi siswa tidak mengetahui apa yang harus 
dikerjakan (Suherman, 2003). Sehingga siswa lebih sering menyelesaikan soal dengan menuliskan rumus (pendekatan fisika) secara tebak-menebak atau mencocokkkan rumus dengan kuantitas yang diketahui pada soal yang diberikan (Azizah et al., 2015). Padahal, pemecahan masalah dengan cara menerapkan pengetahuan dan pemahaman mereka merupakan salah satu tujuan pembelajarn fisika. Oleh karena itu, diperlukan analisis untuk mengetahui sejauh mana tingkat kemampuan pemecahan masalah siswa pada materi suhu dan kalor berdasarkan rubrik Docktor. Hal ini dilakukan sebagai parameter guru dalam mengambil tindakan yang tepat sesuai dengan kekurangan siswa pada kategori-kategori dalam memecahkan masalah.

\section{METODE}

Penelitian ini menggunakan metode deskriptif kuantitatif. Sampel penelitian yaitu siswa SMA Negeri 7 Malang kelas XII sebanyak 32 siswa yang telah menempuh materi suhu dan kalor. Instrumen yang digunakan adalah tes kemampuan pemecahan masalah sebanyak tujuh butir dengan reliabilitas 0,732 .

Hasil tes kemampuan pemecahan masalah dianalisis berdasarkan kategori kemampuan pemecahan masalah yang dikembangkan oleh Docktor yang setiap kategori memiliki rubrik dengan skor 0-5 (Docktor \& Heller, 2009). Skor kemampuan pemecahan masalah yang diperoleh dibandingkan dengan tabel 1 yang menunjukkan kriteria kemampuan pemecahan masalah. Hal ini dilakukan untuk mengetahui tingkat kemampuan pemecahan masalah siswa. Penentuan kemampuan kriteria pemecahan masalah merujuk pada (Azwar, 2010).

Tabel 1. Kriteria Kemampuan Pemecahan Masalah

\begin{tabular}{ccl}
\hline No & Persentase & Kriteria \\
\hline $\mathbf{1}$ & $75 \%<X \leq 100 \%$ & Sangat Tinggi \\
\hline $\mathbf{2}$ & $58 \%<X \leq 75 \%$ & Tinggi \\
\hline $\mathbf{3}$ & $42 \%<X \leq 58 \%$ & Sedang \\
\hline $\mathbf{4}$ & $25 \%<X \leq 42 \%$ & Rendah \\
\hline $\mathbf{5}$ & $0 \%<X \leq 25 \%$ & Sangat Rendah \\
\hline
\end{tabular}

\section{HASIL}

\section{Skor Total Kemampuan Pemecahan Masalah Seluruh Siswa dan Setiap Siswa}

Kemampuan pemecahan masalah siswa diperoleh dari hasil tes. Hasil uji statistik deskriptif nilai kemampuan pemecahan masalah seluruh siswa yang disajikan dalam bentuk tabel 2. Hubungan kemampuan pemecahan masalah setiap siswa dengan persentase skor yang diperoleh ditampilkan pada gambar 1.

Tabel 2. Hasil Statistik Deskriptif Kemampuan Pemecahan Masalah secara Keseluruhan

\begin{tabular}{lccccc}
\hline & N & Minimum (\%) & Maximum (\%) & Mean (\%) & Std. Deviation \\
\hline Skor & 32 & 5 & 68 & 44,08 & 13,437 \\
Valid N (listwise) & 32 & & & & \\
\hline
\end{tabular}

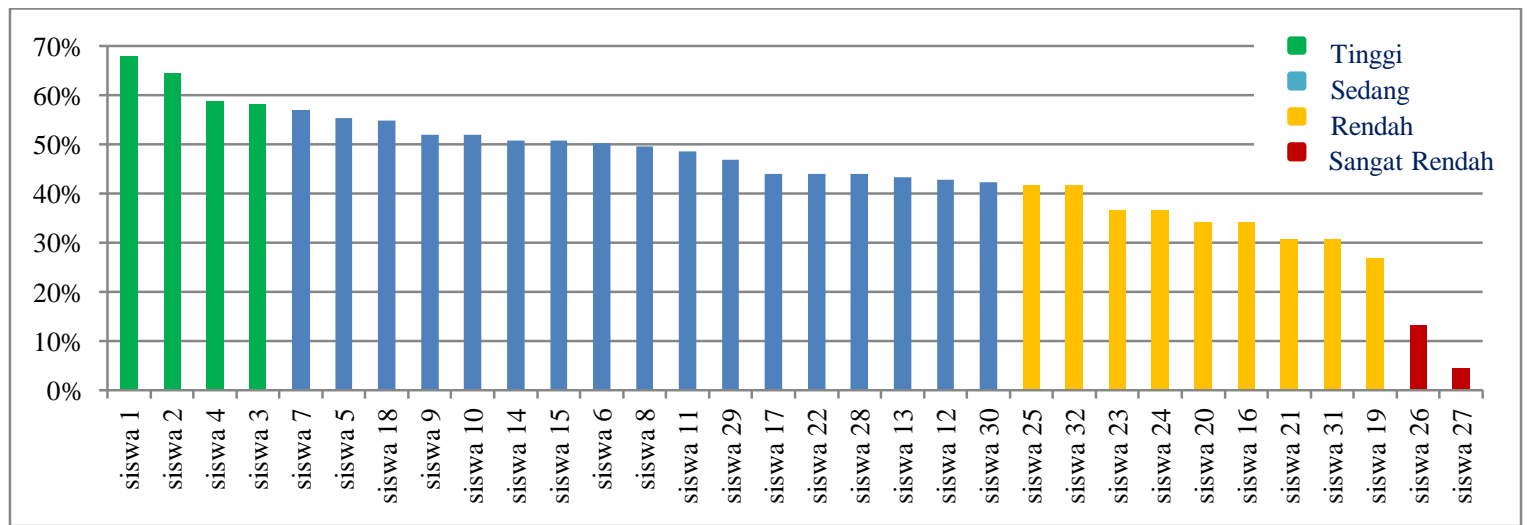

Gambar 1. Diagram Hubungan antara Siswa dengan Persentase Skor Kemampuan Pemecahan Masalah

Berdasarkan tabel 2 diperoleh persentase skor rata-rata siswa 44,08\% dengan skor terendah $5 \%$ dan skor tertinggi 68 $\%$. Skor yang diperoleh masih jauh dari skor ideal yaitu $100 \%$. Oleh karena itu, kemampuan pemecahan masalah siswa secara keseluruhan termasuk dalam kriteria sedang (44,08 \%). Sedangkan, jumlah siswa untuk setiap kriteria dapat dilihat berdasarkan Gambar 1. Siswa yang termasuk dalam kriteria tinggi sebanyak 4 orang (13\%), siswa dengan kriteria sedang sebanyak 17 orang $(53 \%)$, siswa dalam kriteria rendah sebanyak 9 orang (28\%), sedangkan 2 siswa (6\%) termasuk dalam kriteria sangat rendah. 


\section{Skor Kemampuan Pemecahan Masalah Setiap Butir Soal}

Hasil persentase setiap butir soal kemampuan pemecahan masalah yang mampu diselesaikan oleh semua siswa disajikan dalam bentuk tabel 3. Setiap butir soal terdapat lima kategori dalam proses penskoran yaitu UD, PA, SAP, MP, dan LP yang dapat dilihat pada gambar 2 yang disajikan dalam diagram batang.

\section{Tabel 3. Hasil Persentase Setiap Butir Soal Kemampuan Pemecahan Masalah}

\begin{tabular}{ccc}
\hline Nomor Butir soal & Persentase & Kriteria \\
\hline Soal nomor 1 & $85 \%$ & Sangat tinggi \\
Soal nomor 2 & $35 \%$ & Rendah \\
Soal nomor 3 & $62 \%$ & Tinggi \\
Soal nomor 4 & $13 \%$ & Sangat Rendah \\
Soal nomor 5 & $8 \%$ & Sangat Rendah \\
Soal nomor 6 & $54 \%$ & Sedang \\
Soal nomor 7 & $52 \%$ & Sedang \\
\hline
\end{tabular}

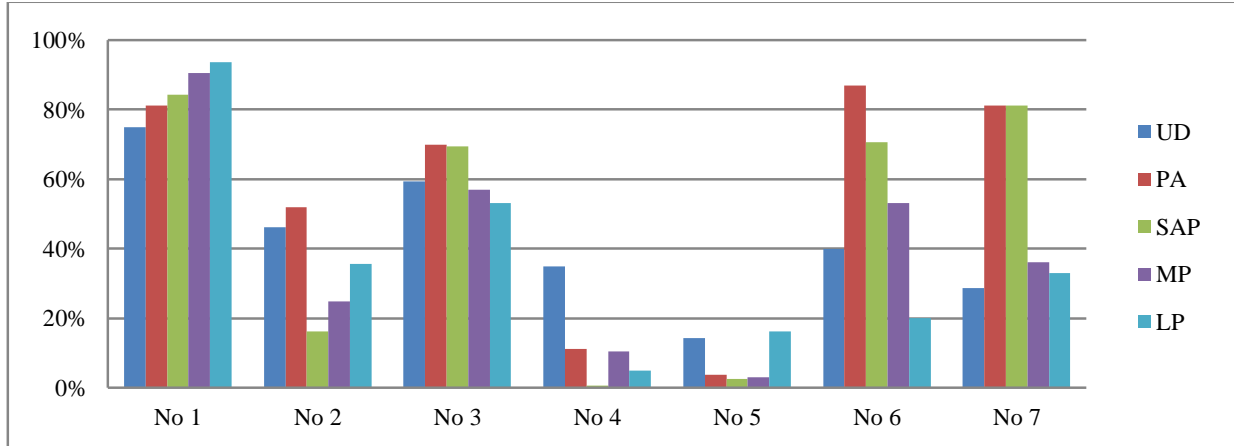

Gambar 2. Diagram Hubungan antara Butir Soal dengan Persentase Skor Kemampuan Pemecahan Masalah

Berdasarkan tabel 3, siswa dapat menyelesaikan soal nomor 1 dengan kriteria sangat tinggi (85\%). Siswa dapat memecahkan soal pemuaian pada benda cair dengan baik. Namun, jika dilihat berdasarkan diagram pada Gambar 2, kategori UD paling rendah. Hal ini dikarenakan beberapa siswa tidak menulis secara lengkap informasi yang ada. Perkembangan logika siswa pada soal nomor 1 paling tinggi, karena siswa dapat mengerjakan dengan logis (penyelesaian secara berurutan) dan konsisten (hasil sesuai dengan harapan kualitatif fisika).

Berdasarkan gambar 2, pada soal nomor 2, 4, dan 5 memiliki karakteristik yang hampir sama yaitu skor pada kategori SAP sangat rendah dibandingkan dengan 4 kategori lainnya (UD, PA, MP, dan LP). Jika dilihat dari Tabel 3, kemampuan siswa dalam memecahkan masalah pada butir soal nomor 2, 4, dan 5 termasuk dalam kriteria rendah dan sangat rendah. Sedangkan soal nomor 3, 6, dan 7 memiliki karakteristik hampir sama yaitu UD, MP dan LP selalu memiliki skor lebih rendah daripada 2 kategori lainnya (PA dan SAP). Jika dilihat dari Tabel 3, kemampuan siswa dalam memecahkan masalah pada soal nomor 3, 6, dan 7 termasuk dalam kriteria tinggi dan sedang.

\section{Skor Setiap Kategori Kemampuan Pemecahan Masalah}

Persentase dan kriteria kemampuan pemecahan masalah siswa secara kesuluruhan disajikan dalam bentuk tabel dapat dilihat pada tabel 4.

Tabel 4. Persentase Kemampuan Pemecahan Masalah Berdasarkan Rubrik Docktor

\begin{tabular}{lcc}
\hline Kategori Pemecahan Masalah Docktor & Persentase & Kriteria \\
\hline Deskripsi yang berguna (UD) & $43 \%$ & Sedang \\
Pendekatan Fisika (PA) & $55 \%$ & Sedang \\
Aplikasi fisika yang spesifik (SAP) & $46 \%$ & Sedang \\
Prosedur matematika (MP) & $39 \%$ & Rendah \\
Perkembangan Logika (LP) & $37 \%$ & Rendah \\
\hline Total & $44 \%$ & Sedang \\
\hline
\end{tabular}

Tabel 4 menunjukkan bahwa kemampuan pemecahan masalah siswa dikelompokkan dalam lima kategori, yaitu UD, PA, SAP, MP, dan LP. Terdapat tiga kategori termasuk dalam kriteria sedang, yaitu UD, PA, dan SAP, sedangkan dua kategori yaitu MP dan LP termasuk dalam kriteria rendah. 


\section{PEMBAHASAN}

\section{Analisis Skor Total Kemampuan Pemecahan Masalah Seluruh Siswa dan Setiap Siswa}

Kemampuan pemecahan masalah siswa secara keseluruhan tergolong dalam kriteria sedang. Hal ini dapat ditunjukkan dari persentase skor total untuk seluruh siswa sebesar 40,08\% (kriteria sedang). Selain itu, ditujukkan dari persentase jumlah siswa terbanyak yaitu pada kriteria sedang (53\% siswa). Hasil ini sesuai dengan penelitian sebelumnya menyebutkan bahwa kemamuan pemecahan masalah siswa pada suhu dan kalor sebesar 53,3\% termasuk dalam kriteria sedang (Ekasari, Diantoro, \& Parno, 2017).

\section{Analisis Skor Kemampuan Pemecahan Masalah Setiap Butir Soal}

Kemampuan pemecahan masalah siswa termasuk pada kriteria rendah dan sangat rendah yaitu ketika siswa menyelesaikan soal nomor 2, 4, dan 5 dengan karakteristik SAP skor rendah. Pada soal nomor 2, siswa tidak menerapkan konsep fisika karena siswa tidak mengisi kategori UD dengan lengkap. Sehingga siswa tidak menentukan koefisien muai panjang dari data yang diberikan pada soal. Padahal seharusnya nilai koefisien muai panjang dicari dari data yang telah diberikan pada soal. Hal ini menujukkan bahwa siswa terlalu tergesa-gesa untuk mengerjakan karena telah memiliki semua kuantitas yang dibutuhkan. Hasil ini sama dengan penelitian sebelumnya yang mengungkapkan bahwa siswa menerapkan plug and chug (Walsh, Howard, \& Bowe, 2007).

Soal dengan karakteristik SAP rendah berikutnya yaitu soal nomor 4 dan 5 tentang pengaruh kalor terhadap perubahan wujud zat. Siswa belum mampu menerapkan asas Black dalam kasus kalor menyebabkan perubahan wujud zat. Hal ini menunjukkan bahwa siswa masih kesulitan terhadap materi kalor. Hasil ini didukung oleh penelitian sebelumnya yang menyatakan bahwa suhu dan kalor salah satu konsep yang sulit dipelajari (Sozbilir, 2003). Contoh penskoran nomor 4 disajikan pada gambar 3.

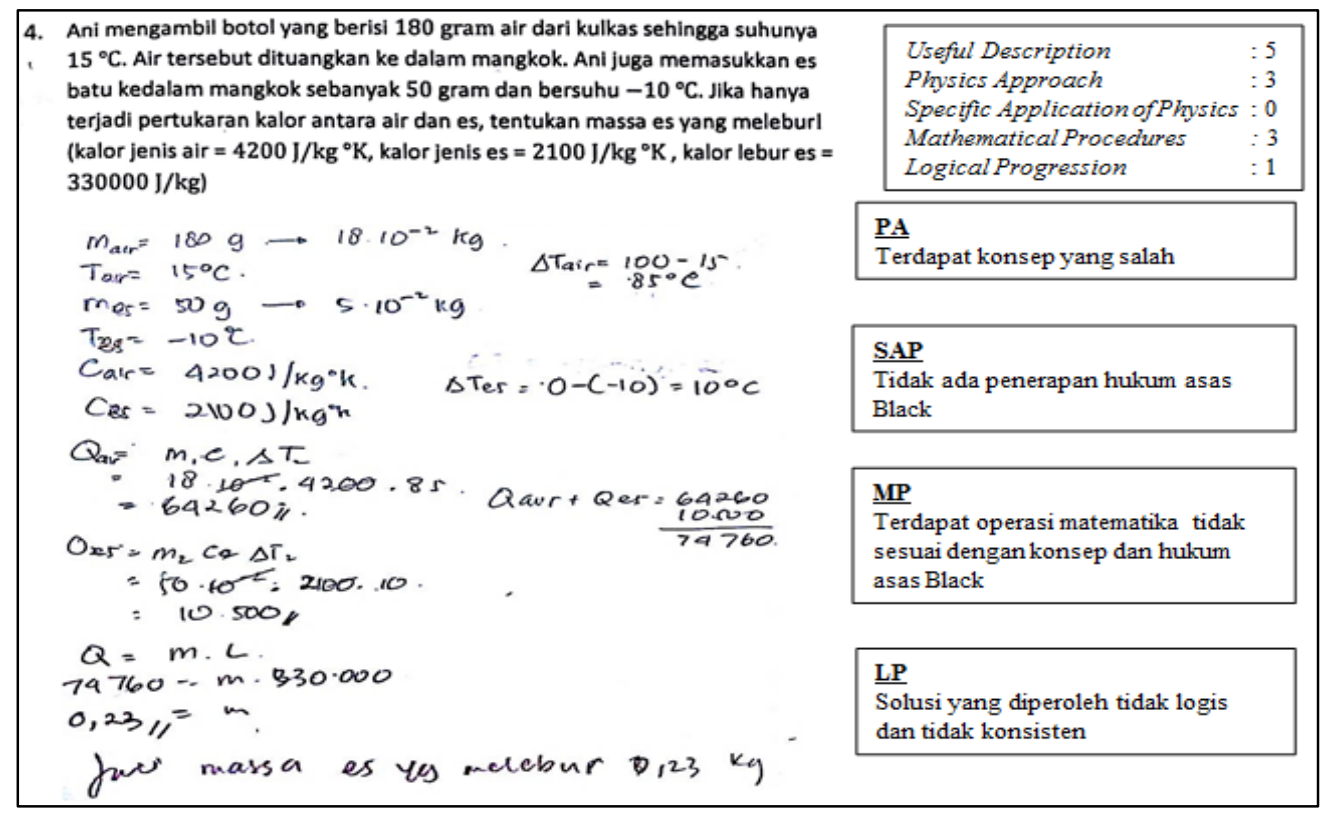

\section{Gambar 3. Contoh Penskoran dengan Karakteristik SAP rendah}

Berdasarkan gambar 3, kategori LP pada soal nomor 4 dikatakan tidak konsisten dan kurang logis, karena hasil yang diperoleh yaitu massa es yang melebur $0,23 \mathrm{~kg}$ sedangkan massa es yang disediakan $0,05 \mathrm{~kg}$. Pada soal nomor 5 juga dikatakan kurang logis dan tidak konsisten, karena grafik yang dibuat bertentangan dengan konsep yang ada. Air mengalami perubahan wujud dari cair menjadi uap pada suhu $100^{\circ} \mathrm{C}$, sedangkan pada grafik yang dibuat siswa yaitu pada suhu $120^{\circ} \mathrm{C}$. Hal ini menunjukkan bahwa siswa kurang teliti sehingga tidak membandingkan hasil akhir yang diperoleh dengan kuantitas yang diberikan pada soal. Hal ini didukung penelitian sebelumnya yang menyatakan bahwa siswa sering melewatkan memeriksa jawaban (Hafizah, Misbah, \& Annur, 2018).

Karakteristik soal nomor 3, 6, dan 7 dengan kategori UD, MP, dan LP selalu lebih rendah daripada PA dan SAP. Sementara itu, kemampuan pemecahan masalah siswa ketika mengerjakan soal nomor 3, 6, dan 7 termasuk dalam kriteria sedang dan tinggi. Namun, pada prosedur matematika turun karena siswa mengalami kendala dalam aturan matematika yang harus digunakan yaitu aljabar. Masih banyak siswa yang kesulitan dalam aturan aljabar (Astuti, 2017; Clement, 2016; Persada \& Sari, 2013). Contoh proses penskoran nomor 3 dengan kategori UD, MP, dan LP yang lebih rendah daripada PA dan SAP dapat dilihat pada gambar 4. 


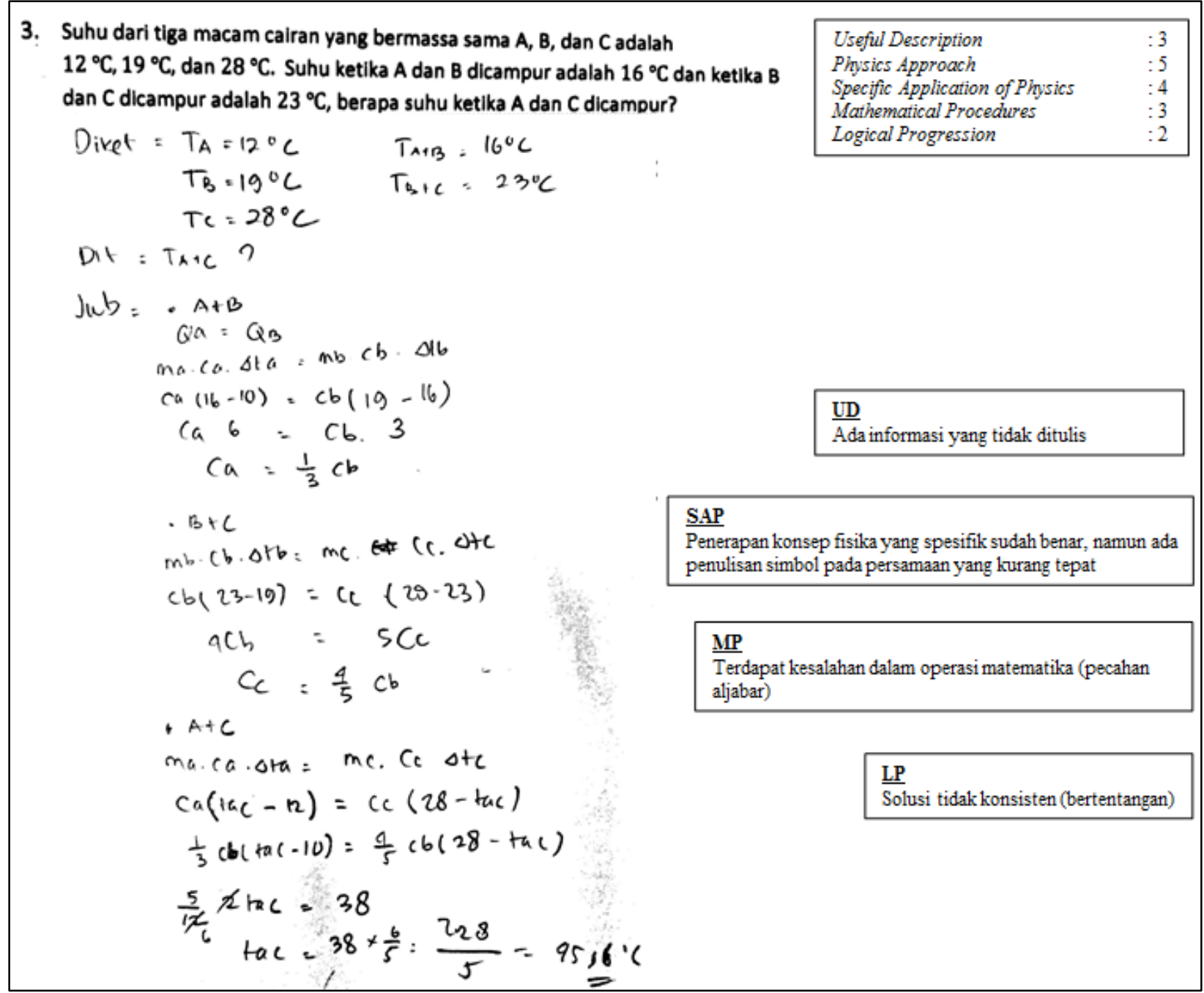

Gambar 4. Hasil Penskoran dengan Karakteristik UD, MP, dan LP selalu lebih rendah daripada PA dan SAP

Pada soal nomor 3 dapat dilihat pada gambar 4 yaitu suhu campuran yang diperoleh tidak berada diantara kedua suhu yang dicamur. Siswa sebenarnya sudah mampu memperkirakan suhu campuran yang harus diperoleh, namun dalam kasus ini siswa cepat merasa puas dengan jawaban yang diperoleh. Sehingga siswa sering melewatkan pemeriksaan kembali terhadap jawaban yang diperoleh (Hafizah et al., 2018). Akibatnya siswa tidak mengetahui bahwa jawaban yang diperoleh tidak logis dan tidak konsisten.

\section{Analisis Skor Setiap Kategori Kemampuan Pemecahan Masalah \\ Useful Description (UD)}

Sebagian besar siswa tidak menulis secara lengkap informasi yang diberikan dan tidak menuliskan tujuan dari permasalahan. Siswa belum mampu menuliskan simbol terhdap kuantitas, sehingga siswa menulis dalam kata-kata. Siswa masih belum mampu membedakan simbol suhu dan simbol waktu. Siswa masih belum mampu dalam penulisan simbol massa dan kalor jenis yaitu menggunakan huruf kapital. Selain itu, banyak siswa yang tidak menulis informasi sama sekali dan langsung menyelesaikan permasalahan. Kasus seperti ini merupakan fakta yang lazim dan banyak ditemukan di lapangan. Penelitian sebelumnya juga menyatakan bahwa siswa dalam mendiskripsikan informasi berada dalam kriteria sedang (Utami \& Wutsqa, 2017).

\section{Physics Approach (PA) dan Specific Application of Physics (SAP)}

Kategori berikutnya yaitu siswa memilih pendekatan fisika (konsep) yang akan digunakan tergolong sedang. Sebagian siswa hanya mampu memilih rumus yang disesuaikan dengan kuantitas-kuantitas yang diberikan. Siswa juga belum mampu menulis semua konsep (rumus matematis) yang dibutuhkan dalam menyelesaikan permasalahan. Bahkan beberapa siswa yang hanya menulis deskripsi yang berguna saja. Sehingga beberapa siswa belum mampu memilih konsep yang sesuai. Kemampuan 
siswa pada kategori aplikasi fisika yang spesifik tergolong dalam kriteria sedang. Sebagian besar siswa masih bingung ketika mengaitkan beberapa konsep atau prinsip. Bahkan ada di salah satu soal yang diberikan, hampir semua siswa tidak mampu mengaitkan konsep yang ada. Siswa juga belum mampu memasukkan kuantitas yang benar ke dalam rumus matematis. Hal ini dikarenakan banyak siswa yang tidak mendeskripsikan permasalahan. Hasil penelitian ini didukung oleh penelitian sebelumnya yang menyatakan bahwa siswa dalam memilih dan penerapan rumus-rumus fisika termasuk dalam kriteria sedang (Widiningtyas, Damayanti, \& Kusairi, 2018).

\section{Mathematical Procedures (MP)}

Kategori prosedur matematika termasuk dalam kriteria rendah. Sebagian besar siswa belum mampu menjalankan auturan matemtika yaitu aljabar dan pecahan. Siswa sering kali menulis secara tidak runtut dalam aturan matematika sehingga sering terjadi kesalahan dalam memperoleh hasil. Kesalahan dalam operasi aljabar juga sering terjadi. Penelitian yang telah dilakukan juga menyatakan bahwa rosedur matematika dalam kriteria rendah (Makrufi, Hidayat, Muhardjito, \& Sriwati, 2016).

\section{Logical Progression (LP)}

Perkembangan logika siswa termasuk dalam persentase paling sedikit dan tergolong kriteria rendah. Penelitian sebelumnya menyatakan bahwa siswa dalam mengkonfirmasi jawaban termasuk dalam kriteria rendah (Ekasari et al., 2017; Hafizah et al., 2018) dan ada juga yang menyatakan dalam kriteria sangat rendah (24,19\%) (Peranginangin \& Surya, 2017). Sebagian besar siswa tidak memikirkan kelogisan dan kekonsistenan jawaban. Ketika sudah memperoleh jawaban siswa langsung berpindah ke soal berikutnya. Sehingga banyak jawaban yang tidak logis dan bertentangan dengan suatu kondisi atau konsep yang ada. Siswa mengalami kesulitan dalam proses memecahkan masalah khususnya pada kategori perkembangan logika (Maliki, Hidayat, \& Sutopo, 2017).

\section{SIMPULAN}

Secara keseluruhan kemampuan pemecahan masalah siswa pada materi suhu dan kalor tergolong dalam kriteria sedang. Berdasarkan analisis setiap siswa terhadap kemampuan dalam memecahkan masalah dikelompokkan menjadi empat kriteria. Keempat kriteria tersebut, meliputi tinggi sebanyak empat siswa, kriteria sedang sebanyak 17 siswa, kriteria rendah sebanyak sembilan siswa, sedangkan sisanya yaitu dua siswa termasuk dalam kriteria sangat rendah. Siswa dengan kriteria rendah hanya mampu menuliskan informasi pada soal, namun tidak lengkap.

Berdasarkan analisis kemampuan pemecahan masalah siswa pada setiap butir soal dikelompokkan menjadi 5 kriteria. Kelima kriteria siswa dalam memecahkan masalah setiap butir soal tersebut antara lain: kriteria sangat tinggi pada soal nomor 1, kriteria tinggi pada soal nomor 3, kriteria sedang pada soal nomor 6 dan 7, kriteria rendah pada soal nomor 2, dan kriteria sangat rendah pada soal nomor 4 dan 5. Siswa banyak mengalami kesulitan dalam menyelesaikan butir soal nomor 4 dan 5 tentang pengaruh kalor terhadap perubahan wujud zat. Sebagian besar siswa belum mampu menerapkan asas Black dalam kasus kalor menyebabkan perubahan wujud zat. Oleh karena itu, siswa perlu dilatih dalam menerapkan asas Black pada perubahan wujud zat.

Berdasarkan analisis setiap kategori kemampuan siswa dalam memecahkan masalah dikelompokkan dalam lima kategori, yaitu UD, PA, SAP, MP, dan LP. Kemampuan pemecahan masalah siswa dalam kategori UD, PA, dan SAP termasuk dalam kriteria sedang, sedangkan ada dua kategori yang masuk pada kriteria rendah, yaitu MP dan LP. Siswa mengalami kesulitan dalam aturan aljabar dan sering melewatkan dalam memeriksa jawaban. Adanya kategori yang tergolong rendah dapat ditingkatkan dengan melatih siswa dengan strategi tertentu. Penelitian lebih lanjut sebaiknya dilakukan penelitian tentang pembelajaran yang mampu mengatasi kekurangan siswa dalam memecahkan masalah.

\section{DAFTAR RUJUKAN}

Alwan, A. A. (2011). Misconception of Heat and Temperature among Physics Students. In International Conference on Education and Educational Psychology (ICEEPSY 2010) (pp. 600-614). https://doi.org/10.1016/j.sbspro.2011.02.074

Astuti. (2017). Analisis Kesulitan Belajar Struktur Aljabar pada Mahasiswa Semester III Jurusan Pendidikan Matematika STKIP Pahlawan Tuanku Tambusai Riau Tahun Ajaran 2015/2016. Jurnal Cendekia: Jurnal Pendidikan Matematika, 1(1), 17-23.

Azizah, R., Yuliati, L., \& Latifah, E. (2015). Kesulitan Pemecahan Masalah Fisika pada Siswa SMA. Jurnal Penelitian Fisika dan Aplikasinya (JPFA), 5(2), 44-50. https://doi.org/10.26740/jpfa

Azwar, S. (2010). Tes Potensi: Fungsi Pengembangan Pengukuran Prestasi Belajar. Yogyakarta: Pustaka Belajar.

Clement, J. (2016). Algebra Word Problem Solutions : Thought Processes Underlying a Common Misconception. Journal for Research in Mathematics Education, 1(1), 16-30. https://doi.org/10.2307/748434

Docktor, J., \& Heller, K. (2009). Robust Assessment Instrument for Student Problem Solving. In Proceedings of the NARST 2009 Annual Meeting (pp. 1-19).

Dunbar, K. (1998). Problem Solving. In A Companion to Cognitive Science (pp. 289-298). London, England: Blackwell. https://doi.org/10.1002/9781405164535.ch20 
Ekasari, A., Diantoro, M., \& Parno. (2017). Kemampuan Pemecahan Masalah Siswa MAN 2 Tulungagung terhadap Materi Suhu dan Kalor. In Seminar Nasional Pendidikan IPA (pp. 110-113). Malang.

Hafizah, E., Misbah, \& Annur, S. (2018). Kemampuan Pemecahan Masalah Mahasiswa pada Materi Mekanika. Momentum: Physics Education Journal, 2(2), 72-78. https://doi.org/http://doi.org/10.21067/mpej.v2i2.2729

Karatas, I., \& Baki, A. (2013). The Effect of Learning Environments based on Problem Solving on Students' Achievements of Problem Solving. International Electronic Journal of Elementary Education, 5(3), 249-268. https://doi.org/10.12973/nefmed201

Makrufi, A., Hidayat, A., Muhardjito, \& Sriwati, E. (2016). Analisis Kemampuan pemecahan Masalah Siswa pada Materi Fluida Dinamis. In Peran Pendidikan, Sains, dan Teknologi dalam Membangun Intelektual Bangsa dan Menjaga Budaya Nasional di Era MEA (pp. 332-340). Jember.

Maliki, I. M. Al, Hidayat, A., \& Sutopo. (2017). Kemampuan Pemecahan Masalah Siswa pada Topik Suhu dan Kalor Melalui Pembelajaran Cognitive Apprenticeship. Jurnal Pendidikan: Teori, Penelitian, dan Pengembangan, 2(2), $304-308$.

Peranginangin, S. A., \& Surya, E. (2017). An Analysis of Students' Mathematics Problem Solving Ability in VII Grade at SMP Negeri 4 Pancurbatu. International Journal Sciences: Basic and Applied Research (IJSBAR), 33(2), 57-67.

Persada, A. L., \& Sari, W. (2013). Pengaruh Kemampuan Berpikir Aljabar terhadap Kemampuan Pemecahan Masalah Matematika (Studi Kasus di Kelas VIII SMP Negeri 1 Kaliwedi Kabupaten Cirebon). Eduma: Mathematics Education Learning and Teaching, 2(2). https://doi.org/10.1039/c3ra42090f

Reeve, E. M. (2016). 21st Century Skills Needed by Students in Technical and Vocational Education and Training. Asian International Journal of Social Sciences, 16(4), 62-74. https://doi.org/aining (TVET). Asian International Journal of Social Sciences, 16(4), 62 - 74. https://doi.org/10.29139/aijss.20160404

Scott, C. L. (2015). The Futures of Learning 3: What Kind of Pedagogies for the 21st century? UNESCO Education Research and Foresight, Paris. https://doi.org/10.1016/j.pse.2015.08.005

Silung, S. N. W., Kusairi, S., \& Zulaikah, S. (2016). Diagnosis Miskonsepsi Siswa SMA di Kota Malang pada Konsep Suhu dan Kalor Menggunakan Three Tier Test. Jurnal Pendidikan Fisika, dan Teknologi, 2(3), 95-105.

Sozbilir, M. (2003). What Students' Understand from Entropy?: A review of selected literature. Journal of Baltic Science Education, 20(1), 25-41.

Suherman, E. (2003). Strategi Pembelajaran Matematika Kontemporer. Bandung: JICA Press.

Utami, R. W., \& Wutsqa, D. U. (2017). Analisis Kemampuan Pemecahan Masalah Matematika dan Self-Efficacy Siswa SMP Negeri di Kabupaten Ciamis. Jurnal Riset Pendidikan Matematika, 4(2), 166-175. https://doi.org/http://dx.doi.org/10.21831/jrpm.v4i2.14897

Walsh, L. N., Howard, R. G., \& Bowe, B. (2007). Phenomenography Study of Students' Problem Solving Approach in Physics. Physics Education Research, 3(2), 1-12. https://doi.org/10.1103/PhysRevSTPER.3.020108

Widiningtyas, A., Damayanti, R. F., \& Kusairi, S. (2018). Analisis Kemampuan Siswa dalam Memecahkan Masalah Rangkaian Arus Searah. In Aktualisasi Peran Generasi Milineal Melalui Pendidikan, Pengembangan Sains, dan Teknologi dalam Menyongsong Generasi Emas 2045 (pp. 190-196). Jember.

Yolanda, R., Syuhendri, \& Nely Andriani. (2015). Analisis Pemahaman Konsep Siswa MA Negeri Se-Kecamatan Ilir Barat I Palembang pada Materi Suhu dan Kalor dengan Instrumen TTCI dan CRI. Inovasi Pembelajaran Fisika, IPA dan Ilmu Fisika dalam Menyiapkan Generasi Emas 2045, 3(1), 86-99. 